\title{
Studies of Lipids and Proteins in a Wild Species of the Arachis (Fabaceae) Gender
}

\author{
A. N. Giannuzzo, N. R. Grosso and C. A. Guzmán \\ ICTA Instituto de Ciencia y Tecnología de Alimentos, Av. Vélez Sarfield 1600. (5016), Córdoba Ar- \\ gentina \\ E-mail: nancygiannuzzo@hotmail.com
}

\begin{abstract}
Chemical components of eight wild species of Arachis were studied. The objectives were to know the chemical composition and establish chemotaxonomic relationships. The results indicate that $A$. villosa is suitable for breeding program of cultivated peanut. $A$. monticola and A. batizocoi showed major chemical affinity with A. hipogaea.
\end{abstract}

\section{Introduction}

The chemical composition of the Arachis hipogeae (peanut) has been extensively studied [1-5] for being the cultivated species of the Arachis gender, however, studies of the wild species are limited.

The knowledge of this plant could facilitate methods of crossing among them with cultivation of $A$. hipogeae in order to obtain seeds of optimum quality.

The objectives of this paper are: 1) To determine the lipidic-proteic chemical composition of seeds of wild species of Arachis, to contribute to the chemical knowledge of the species 2) To establish possible chemotaxonomic relationships 3) To contribute to the plans of genetic improvement of A. hipogeae.

\section{Experimental}

Wild seeds of Arachis (A. correntina, A. duranennensis, A. monticola, A. batizocoi, A. cardenasii, A. helodes, A. chacoensis y A. villosa) were used. The total contents of protein was determined (kjeldahl) and the extraction of oil for quantification was carried out.

The methyl esters of fatty acids were quantized and identified (GC), and also the iodine indexes were determined. The results were presented in a phenograph and in two- and three-dimensional graphics.

\section{Results and Discussion}

The results of the chemical studies of the peanut s wild species showed that: 1) A. batizocoi is the 
species that contains the highest percentage of oil and A. villosa the highest protein content 2) The best oleic/linoleic relation and iodine index are found in A. villosa 3) The samples of the wild species (except $A$. villosa) present a lower oleic/ linoleic relation and higher iodine indexes than the cultivated peanut 4) In relation to the numerical analysis, it can be observed that some samples of species separate one from each other because they have little chemical affinity, meaning they have differences at the level of their genotypes 5) The species more chemically related by affinity to the cultivated peanut are A. monticola and A. batizocoi.

\section{Acknoledgements: To CONICET, CONICOR , CEPROCOR e INTA de Manfredi (Córdoba).}

\section{References and Notes}

1. Ahmed, E.H.; Yong, C.T Composition, nutrition and flavor of peanut. Peanut Science and Technology; Pattee, H. E.; Yong, C.T., Eds.; American Peanut Reseach and Education Society. Inc.: Yoakum, Texas, USA, 1982, pp 655-678.

2. González, R. D.; Guzmán, C.A. Composición proteínica de semillas de los cultivares de maní de la provincia de Córdoba (Argentina). Oyton 1982, 42(2), 179.

3. Grosso, N.R.; Guzman, C.A. Protein, oil content, and fatty acid composition of bolovian grundnut cultivars. International Arachis Newsletter 1991, 9, 20.

4. Maldonado, E. M.; Guzmán, C.A. Contenidos de algunos elementos y cenizas totales en semillas de nueve cultivares de maní de la Provincia de Córdoba (Argentina). Oyton 1982, 42(2), 185.

5. Yong, C. T.; Hammons, R. O. Variations in the protein levels of a widw range of peanut genotypes (Arachis hypogaea L.). Oleagineux 1973, 28(6), 293.

6. Banks, D.J. Peanuts germoplasm resources. Crops Sci. 1976, 16, 499.

7. Gregory, W.C.; Gregory M. P.; Krapovickas A.; Smith B.W.; Yarbrough. Structures and genetic resources of peanuts. Peanuts-Culture and Uses 1973, 47-133. American Peanut Research and Education Association, Inc., Stillwallter Okla. 